\title{
PENGEMBANGAN KURIKULUM PENDIDIKAN AGAMA ISLAM MUSLIM MINORITAS: PESANTREN NURUL YAQIN PAPUA BARAT
}

\author{
Ismail Suardi Wekke ${ }^{1}$
}

\begin{abstract}
Since the founding of Indonesia as a nation, madrasah already contribute to education. This history reflects madrasah to accelerate people need on education. After long time, madrasah not only stimulate muslim society in education but also at large field of life. Therefore, this paper explores how the process in madrasah to enhance curriculum. In addition, the study will focus how the administrator of madrasah activate curriculum to extend the environment in minority muslim. This study was conducted in qualitative approach. To step up the process of analysis, case study was implemented. During data collection, in-depth interview and non-participant observation were employed. Interview guidelines and observation sheet were carried out to direct the study. Research findings shows that madrasah in minority muslim, in this study is Pesantren Nurul Yaqin, formulates some programs and activities to develop the madrasah curriculum. Some programs were practiced to accumulate information from parents, practitioner, and decision maker. There are several processes to enlarge participation and invite people to contribute to the learning material in curriculum. The institution on multiethnic and multicultural society has challenge to synchronize aspiration form different side. On this opportunity to contribute, madrasah accelerate its curriculum in expanding this environment condition. Finally, this research conclude that madrasah in minority muslim on curriculum advancement has chance to encourage students competency that differ from other majority muslim.
\end{abstract}

Keywords: curriculum, enhancement, minority, society.

\section{A. Pendahuluan}

Tantangan demi tantangan dihadapi para pelajar dan dunia pendidikan. Dinamika lingkungan bergerak dengan lebih cepat dibandingkan dengan masa sebelumnya. Bahkan setiap saat ditemukan inovasi teknologi yang lebih baik. Keadaan ini memberikan peluang bagi setiap aspek kehidupan untuk mengikuti ritme ini atau ditinggalkan.

1 Dosen Fakultas Tarbiyah Sekolah Tinggi Agama Islan Negeri Sorong Jl. Klomono-Sorong KM. 17 Klablim Sorong Papua Barat 
Dengan kondisi seperti ini, maka pelaku pendidikan harus berusaha secara berkelanjutan untuk menyiapkan peserta didik dalam beradaptasi dengan dinamika tadi. Tuntutan yang dihadapi adalah pendidikan harus meningkatkan kepekaan dalam merancang dan menerapkan inovasi (Lubis, Wekke, dan Syafar, 2009: 282). Dengan demikian, pendidikan tidak hanya sekedar menjadi rutinitas belaka yang kehilangan makna. Tetapi sebaliknya pendidikan menjadi dinamisator bagi kehidupan. Kecenderungan gelombang ketiga pendidikan dalam skala antarabangsa menunjukkan kondisi yang kompleks (Mazzarol, Soutar, dan Yaw Seng, 2003). Lembaga-lembaga pendidikan tidak saja berfungsi untuk sekedar mendidik tetapi juga harus memastikan kompetensi keilmuan lulusan yang dicetak.

Bagi menghadapi tantangan ini, maka tidak ada pilihan bagi lembaga pendidikan kecuali dengan melakukan perencanaan serta usaha yang sistemik dan optimal, dalam rangka menyiapkan perangkat sistem pendidikan dalam lingkup sekolah. Dengan penataan sejak awal, maka proses pendidikan akan berjalan secara terarah. Komponen awal yang perlu diperhatikan adalah kurikulum. Unsur kurikulum ini akan menggambarkan kompetensi lulusan yang diharapkan. Sekaligus memandu administratur untuk menjalankan proses dan kelangsungan material pendidikan. Makna ini sama dengan pengertian yang dikemukakan Muhaimin (2005: 1) dengan melihat kurikulum sebagai jalan terang. Ini dapat saja berarti bahwa kurikulumlah yang akan memandu keseluruhan proses pendidikan yang ada. Sekaligus sebagai pedoman dalam merancang tahapan berikutnya dalam setiap pengalaman belajar yang sistematis dan logis.

Hasil penelitian para sarjana dalam penelitian pengembangan kurikulum terbagi dalam tiga kelompok. Pertama, keterlibatan kelompok eksternal dalam penyusunan kurikulum (Osteneck, 2011), termasuk dalam memperhatikan lingkungan (Tibble, 2009) dan kolaborasi antarabangsa untuk memenuhi tuntutan banyak lembaga (Kushnarenko, 2010). Kedua, penggunaan data pendukung untuk mengembangkan kurikulum (Siler, 2009). Terakhir, tradisi dan kepemimpinan yang mendukung proses pengembangan kurikulum (Castineira, 2009). Dari ketiga kategori penelitian tersebut dapat disimpulkan bahwa penyusunan kurikulum senantiasa tidak dapat melepaskan diri pada tuntutan eksternal. Sehingga dalam proses penyusunan diperlukan data dan masukan dari pelbagai kalangan. Begitu pula selama proses pengembangan kurikulum tidak 
dapat dinafikan kehadiran kepemimpinan yang kuat untuk mewujudkan konsep yang diinginkan bersama. Selanjutnya, ada pula tradisi yang senantiasa harus dipertahankan tanpa harus melihat faktor eksternal yang dijadikan sebagai landasan pemikiran. Namun, tradisi ini justru lahir dari proses internal.

Penelitian pendidikan Islam selama ini masih berada dalam arus utama dalam konteks muslim mayoritas. Dimana pendidikan Islam berkembang seiring dengan kesadaran bersama dalam jumlah yang besar. Hanya saja, ada realitas dimana muslim minoritas juga tetap melakukan pengembangan pendidikan dalam skala lokal. Baik mayoritas maupun minoritas, keislaman senantiasa menjiwai pergumulan pendidikan Islam dengan wilayah yang ditempatinya. Beberapa penelitian mutakhir dalam kajian pendidikan Islam berkenaan dengan kurikulum antara lain dilaksanakan Howell (2010) dengan kesimpulan bahwa sufisme tidak secara khusus menggunakan kurikulum dalam aktivitas pembelajaran. Sementara penelitian Andaya (2013) menyimpulkan bahwa dalam beberapa kajian dalam pendidikan Asia memberikan posisi yang khas bagi perempuan. Pengembangan kurikulum senantiasa memperhitungkan posisi perempuan sebagai salah satu pelaku pendidikan. Demikian pula penelitian SmithHefner (2008) yang juga menjelaskan temuan bahwa perempuan sebagai aktor pendidikan yang utama. Kurikulum juga, walaupun tidak hanya dimaksudkan untuk itu saja, dapat menjadi sarana untuk membangun resolusi konflik yang terjadi (Nir dan Eyal, 2003). Masalah sosial dapat diatasi melalui desain kurikulum yang memadai (Medoff, 2008). Dari penelitian-penelitian tersebut dapat disimpulkan bahwa perhatian para sarjana berkenaan dengan pendidikan Islam baru dalam kajian bidang-bidang tertentu. Kajian yang khusus melakukan pengamatan berkenaan dengan muslim di kawasan minoritas belum dipublikasikan. Sehingga dengan penelitian ini akan turut memberikan gambaran dinamika pendidikan Islam di wilayah muslim minoritas.

Penelitian kurikulum diperlukan untuk memberikan gambaran bagaimana ide-ide atau konsep pengembangan kurikulum untuk menjadi acuan dalam pendidikan. Dengan adanya informasi seperti ini akan menjadi bahan dalam merefleksikan secara kritis bagaimana proses yang sudah berjalan dalam mengadminsitrasikan kurikulum. Kurikulum menjadi keterkaitan dengan komponen pembelajaran lainnya dimana dengan dalam kurikulum dirumuskan tujuan untuk mengembangkan potensi peserta didik. Saat tujuan yang hendak dicapai sudah termaktub, 
maka metode yang digunakan untuk mencapai tujuan itu juga disertakan. Secara bersamaan pula ada kegiatan evaluasi yang akan digunakan sebagai alat dalam memberikan umpan balik akan pencapaian yang diinginkan. Dari sisi ini, maka penelitian kurikulum menjadi bagian yang perlu dilakukan dalam rangka merumuskan dan mengembangkan kerangka asumsi untuk pembentukan pendidikan. Dengan pengalaman berharga yang diidentifikasi peneliti akan menjadi sumbangsih untuk menggambarkan proses pendidikan yang berkesinambungan. Untuk itu, artikel ini bertujuan untuk mengidentifikasi pola pengembangan kurikulum di Pesantren Nurul Yaqin dengan memperhatikan faktor lingkungan muslim minoritas.

\section{B. Pengembangan Kurikulum dan Dinamika Lingkungan}

Dinamika kontekstual lingkungan memberikan dampak bagi perlunya pengembangan kurikulum. Dalam satuan pendidikan, seperti di Bali (Jannah, 2012) tidak saja pendidikan sebagai sarana formal untuk transformasi keilmuan. Tetapi lebih dari itu, sekaligus menjadi sarana untuk merajut persaudaraan. Pendidikan tidak diarahkan menjadi fanatisme beragama yang pada akhirnya dapat memicu bentrokan komunal. Justru pendidikan dibumikan dan tidak diasingkan dari lingkungan yang mewadahinya. Begitu pula agama harus menjadi pembebas bagi kehidupan serta tidak berada dalam situasi romantisme formal. Dengan kondisi ini, maka tuntutan lingkungan yang mendorong untuk melakukan pengembangan kurikulum berdasarkan keperluan masing-masing. Sementara itu tidak menafikan tuntutan regional dan nasional. Sehingga peserta didik kemudian dapat saja menjadi warga dalam skala lokal begitu pula regional dan nasional.

Dalam istilah Lewin (1936) ini disebut sebagai life space (ruang hidup). Kondisi lingkungan yang dihadapi setiap individu kemudian perlu diwadahi dalam lembaga pendidikan. Pengaruh lingkungan secara individual perlu ditemukan kemudian dikembangkan sesuai dengan rata-rata keadaan peserta didik. Termasuk pula didalamnya adalah pembentukan ruang ini karena faktor persepsi. Dengan keberadaan individu dalam lingkungannya masing-masing, akan memberikan cara berperilaku. Cara ini tidak bisa dibandingkan antara satu lingkungan dengan lingkungan yang lain. Maka, kurikulum dikehendaki menjadi ruang untuk memberikan latihan bagi pembelajaran 
untuk mengekspresikan individu dalam lingkungannya di masa depan. Ini berkaitan dengan keberadaan pendidikan hari ini untuk kehidupan masa kini dan yang akan datang. Dalam hubungan dengan kurikulum, wilayah utara di Australia menggunakan lingkungan kelas dalam rangka mengembangkan kurikulum (Bat dan Fasoli, 2013). Ada interaksi dua arah yang digunakan untuk mendapatkan input dari peserta didik. Gambaran ini berarti bahwa kepentingan pendidikan sesungguhnya terletak di pihak peserta didik itu sendiri.

Wawasan inilah yang dikembangkan secara terus menerus dalam dunia pendidikan yang digagas Wertheimer (1945). Wawasan dibangun sejak awal dari minat terhadap lingkungan secara praktis. Dengan hanya mengandalkan pada hapalan dan ingatan buta, maka akan mengorbankan unsur pemahaman. Secara berpihak, Wertheimer mengemukakan perlunya ada wawasan dalam setiap pembelajaran. Pada saat seorang siswa menghadapi masalah, maka untuk menyelesaikan masalah itu diperlukan dua hal, yaitu pengalaman dan wawasan. Ketika hanya menumpukan semata-mata pada pengalaman saja, maka diperlukan waktu yang cukup lama untuk mengalami secara sendiri. Tetapi dengan wawasan, maka pengalaman ini bisa dengan mendapatkan pengalaman dari pengalaman orang lain. Ini berarti ada restrukturisasi dalam situasi sosial baru yang ditunjang dengan wawasan yang ada. Ketika pengalaman, wawasan, dan restrukturisasi berada dalam siklus yang saling berkaitan, maka akan memberikan dukungan bagi penyelesaian masalah secara benar.

Dengan pemahaman yang nyata disertai dengan logika, seorang siswa dapat menalar untuk menuju kepada sebuah kesimpulan. Penguasaan terhadap lingkungan, akan memberikan dorongan terhadap aktivitas pembelajaran yang berorientasi terhadap pemenuhan kebutuhan dan tuntutan lingkungan. Kajian Dicks dan Batey (2013) menunjukkan bahwa dalam pendidikan kimia sekalipun, prinsip dan praktik yang dijalankan senantiasa memperhatikan kepentingan orang yang berada di luar laboratorium. Pendekatan yang dilakukan berasal dari dua hal baik secara teori maupun tinjauan praktis untuk menerapkan proses pembelajaran yang relevan dengan studi kasus. Ini menunjukkan bahwa sebuah pembelajaran tidak dapat mengislolasi diri dari pihak eksternal. Ketika tidak ada hubungan langsung sekalipun, tetap saja pihak luar dijadikan sebagai salah satu pertimbangan dalam pengayaan proses pembelajaran. 
Arus utama teori pendidikan memandang pembelajaran berada dalam dua kelompok utama yaitu teori koneksionis dan teori kognitif. Dalam teori koneksionis memandang pembelajaran sebagai koneksi (hubungan) antara stimulus dan respon. Hubungan ini berada dalam konteks bagaimana seseorang memberikan respon terhadap stimulus yang diterima (Smith dan MacGregor, 2009). Dengan demikian, kurikulum akan terbentuk beradasarkan stimulus yang dipahami oleh administratur pendidikan. Sementara yang kedua adalah teori koginitif yang memusatkan perhatian pada sikap dan keyakinan sebagai variabel yang kompleks. Kognisi yang sudah terbentuk, akan mendapatkan modifikasi dari dari berubahnya pengalaman yang ada. Untuk itu, dalam posisi ini kurikulum akan dibentuk berdasarkan persepsi yang sudah ada sebelumnya. Kemudian ditambahkan dengan adanya modifikasi berdasarkan informasi tambahan yang ada. Adapun kecenderungan untuk memilih salah satu diantaranya, tergantung pada proses pembelajaran yang dilakukan. Namun, tidak menutup kemungkinan untuk menggabungkan prinsip-prinsip kedua teori ini untuk mendapatkan penyesuaian dengan praktik yang berlangsung di lapangan. Perbedaan keduanya tidak berupa berlawanan dua kutub karena ada juga prinsip pembelajaran yang dikembangkan keduanya saling bersinggungan.

Keterhubungan antara lingkungan dan anggota masyarakatnya menjadi penting karena keberadaan lingkungan yang akan menjadi tempat aktualisasi warga. Ketidaksinkronan antara warga dengan lingkungannya akan menimbulkan keterasingan. Dengan kondisi ini, maka diperlukan senantiasa menenlatkan konteks seorang warga sesuai dengan keberadaanya dalam lingkungan yang didiaminya. Dalam proses internalisasi, maka menyimak, kemudian menyimpan sampai mengingat kembali sebuah pengalaman adalah proses kognitif yang berlangsung tidak serta merta. Tetapi memerlukan proses yang berkesinambungan. Dalam empat rangkaian pendidikan yang dimulai dari kemampuan awal, kemudian tujuan pendidikan, selanjutnya metode pelatihan, dan terakhir pada prosedur evaluasi (Holden dan Griggs, 2010). Kesemua ini menjadi siklus pengalaman belajar yang diharapkan akan memberikan pengayaan keterampilan.

Budaya dijadikan sebagai salah satu unsur untuk meninjau sebuah kurikulum. Sebagaimana dalam penelitian Gervedink, Pieters, dan Voogt (2013) ditunjukkan bahwa praktik di Ghana menghindari kesalahan 
implementasi kurikulum dengan melakukan upaya pemahaman terhadap budaya. Pelaku pendidikan dan pemangku kepentingan dalam bidang pendidikan sejak awal mengidentifikasi budaya dan tradisi masyarakat dalam rangka membangun konsep kurikulum. Hasilnya, kurikulum sebagai alat untuk memfasilitasi pembelajaran sesuai kondisi masyarakat. Pada keberlanjutan proses pendidikan, kurikulum mendapatkan dukungan dan partisipasi dari peserta didik dan lembaga pendidikan. Jika sejak awal kurikulum deprogram sebagai bentuk dari komunikasi dengan lingkungan, maka penolakan dan kesalahan perancangan akan dapat diminimalisir sejak awal. Ini berarti bahwa kesesuaian antara program pendidikan dengan lingkungan menjadi salah satu syarat mutlak kelangsungan pendidikan yang diinginkan.

Pendekatan sosiokultural melihat pembelajaran sebagai partisan. Dalam komunitas, maka amalan dan praktik yang menjadi tolok ukur. Tidak sekedar saja melambangkan agama sebagai identitas kultural. Tetapi lebih dari itu, mendorong adanya pemahaman komprehensif terhadap agama kemudian menjadikan agama sebagai konstruksi dalam kegiatan sehari-hari. Berkenaan dengan identitas, maka maka ini menjadi sudut pandang yang diciptakan dalam konteks sosial. Maka strategi umum dalam pembelajaran untuk mempertautkan konteks dan budaya yang ada. Pada saat yang sama, juga harus memperhatikan kebutuhan dan variasi setiap perseorangan untuk menjadi pembelajar yang lebih baik. Secara umum, kurikulum yang sudah ditetapkan sebagai sistem nasional tidak akan mewakili semangat lingkungan setiap wilayah. Untuk itu diperlukan identifikasi dari sistem ke implementasi dalam kelas. Materi yang disajikan harus melalui proses komunikasi dengan masing-masing lingkungan. Gerrard, Albright, Clarke, dkk (2013) menjelaskan dua hal dalam pembaruan kurikulum. Aspek wilayah dan tuntutan kurikulum harus diselaraskan dalam wujud implementasi di dalam kelas. Ini bermakna, pendidikan tanpa memperhatikan aspirasi lingkungan hanya semata-mata menjadi kepentingan birokrasi.

Siswa akan mempelajari dari orang lain dan lingkungan berupa tindakan-tindakan yang disebut dengan behaviorisme. Banyak hal yang dilakukan individu akibat dari dari perilaku orang lain. Ada usaha untuk mengimitasi pihak lain. Ataupun akan melakukan hal yang berlawanan dengan apa yang dilakukan oleh orang lain dalam bentuk diskrminasi. Perkembangan kepribadian dapat saja mengikuti seseorang dalam bentuk pemodelan (modeling). Dalam proses belajar, imitasi dan 
mengamati pengalaman dari keberhasilan orang lain akan meningkatkan kecepatan bahkan peluang untuk menjalani proses belajar dengan lebih baik. Jika harus melalui proses yang dibentuk siklus, maka dapat saja terjadi kelambatan dan kesulitan dalam pembelajaran (Ford, 2004). Dengan belajar seperti ini, akan memberikan respon yang relatif baru dan dengan cepat diolah sebagai bagian informasi untuk belajar.

Dalam proses imitasi ini ada respon yang diberikan. Begitu pula ada elisitasi (elicitacion) yang berlangsung secara cepat. Tidak saja dilakukan anak-anak tetapi juga orang dewasa. Walaupun tidak ada kesempatan untuk melakukan apa yang dilihat, pada saat tertentu kemudian akan terekspresi dalam bentuk aktivitas yang terbatas. Tidak selalu mudah untuk menyatakan bentuk elisitasi tersebut karena ada hasrat positif untuk menjalankan aktivitas selanjutnya memberikan respon atas apa yang sudah diamati walaupun sudah tersimpan dalam jangka waktu yang relatif lama. Pada bagian ini berlaku juga imbalan dan hukuman. Maka imitasi dan dilanjutkan dengan elisitasi akan berkembang jika lingkungan kemudian memberikan imbalan dalam setiap aktivitas. Ada penguatan-penguatan dalam pembelajaran yang dibarengi dengan imbalan yang datang sebagai respon dari pembelajaran tersebut. Ketika ada imbalan, maka tingkat akurasi pemodelan akan semakin berkembang ke arah yang lebih baik. Bahkan anak-anak dalam proses pemodelan akan sangat bergantung walaupun tidak sepenuhnya pada bentuk imbalan dan hukuman ini (Moore, 2004).

Sebagai respon terhadap lingkungan, maka setiap individu akan memiliki motivasi dalam tingkat yang berbeda-beda. Pengamatan dan proses pembelajaran akan dituntun untuk mengimitasi orang lain dalam skala yang sama dengan motivasi itu. Ada bentuk penguatan untuk menjalankan proses pembelajaran. Sebaliknya juga imitasi tidak berlangsung ketika penguatan tidak berlangsung dengan baik. Dalam skala yang praktis, pandangan ini bisa saja diterima tetapi dengan memungkinkan adanya pandangan-pandangan lain yang dapat diterima. Ada kesadaran dalam beraktivitas dan itu selalu didorong karena akan ada akhir yang diharapkan pada bagian akhir setelah seluruh rangkaian proses selesai. Penilaian akan dimulai atau diakhiri dengan informasi yang terbatas yang diperoleh dari lingkungan. 


\section{Metode Penelitian}

Penelitian ini dilaksanakan dengan menggunakan pendekatan kualitatif dalam ragam studi kasus. Pendekatan kualitatif menjadi pilihan dengan memperhatikan kesesuaian antara masalah dengan obyek penelitian. Dengan demikian pendekatan yang digunakan dapat menjawab pertanyaan penelitian dengan maksimal. Dengan operasional studi kasus, penelitian ini menyelidiki sebuah program yang tercakup dalam pengembangan kurikulum. Adanya pembatasan terhadap waktu dan aktivitas, maka prosedur yang dijalankan dalam strategi studi kasus akan memberikan informasi yang memadai sebagai hasil penelitian. Secara simultan tiga langkah yang dilakukan sejak pengumpulan data sampai pada penyajian data yaitu mereduksi data menjadi sederhana, intrepretasi sehingga menjadi kesimpulan, dan menampilkan data dengan sajian yang menyeluruh. Creswell (2009: 19) menyebut ragam ini dengan strategi dalam pendekatan kualitatif. Dengan strategi studi kasus secara khusus fenomena pengembangan kurikulum di Pesantren Nurul Yaqin dapat ditelusuri dengan lebih seksama. Pembatasan pada program dan aktivitas secara khusus dalam hal pengembangan kurikulum akan memberikan ruang lingkup sekaligus upaya menjabarkan parameter penelitian secara detail. Putra (2012) juga menyatakan bahwa studi kasus merupakan strategi untuk menghimpun dan menganalisis sebuah program. Sehingga pada analisis sebuah kondisi, dapat melihat perkembangan dan kegiatan serta faktor yang menunjang kegiatan tersebut.

Pengumpulan data dilakukan dengan teknik wawancara mendalam dan observasi tidak berpartisipasi. Wawancara dilakukan kepada guruguru yang terlibat dalam pengembangan kurikulum, pegawai tata usaha dan juga pimpinan pondok pesantren. Pengumpulan data dilakukan selama tiga bulan. Untuk wawancara digunakan instrumen pedoman wawancara. Sementara selama observasi digunakan lembar panduan observasi. Kedua instrumen ini untuk membantu peneliti demikian pula untuk tetap mempertahankan objektifitas pengumpulan data dari aspek subyektif peneliti. Ketika analisis, data yang dikumpulkan melalui tahapan verifikasi dengan sumber lain. Dengan proses triangulasi data seperti ini, maka sejak awal pengumpulan data dijalankan dalam kerangka usaha memperoleh data yang sahih. Selanjutnya untuk menjamin validitas data, maka pengumpulan data diperpanjang sampai lima bulan untuk melakukan uji keabsahan dan kesahihan data 
yang sudah ada melalui focus group discussion. Begitu pula dilakukan pengecekan teman sejawat dan konsultasi kepada sarjana pakar untuk menjamin bahwa data yang sudah ada sudah melalui tahap pengecekan bertingkat.

Untuk menghindari data yang bias, maka observasi dilakukan dengan tidak berpartisipasi. Ada jarak yang diusahakan untuk dikembangkan antara subyek penelitian dengan peneliti. Kehadiran peneliti selama pengumpulan data diusahakan tidak menjadi faktor yang mengintervensi lapangan penelitian. Ini dilakukan sebagai upaya untuk menjaga naturaistik lingkungan penelitian. Sebelum sampai ke lapangan penelitian, maka tahapan awal yang diselesaikan adalah menghimpun kerangka acuan untuk memandu pengumpulan dan analsis data. Dalam pandangan Baxter dan Chua (2008) ini perlu dilakukan untuk membingkai nalar peneliti sebelum terjun ke lapangan. Maka dengan adanya kerangka yang dibuat dapat menjadi panduan sekaligus alat analisis untuk menjawab masalah penelitian.

\section{Realitas Pendidikan Muslim Minoritas}

Lahan pondok diwaqafkan oleh seorang tokoh muslim, Bapak Koya yang juga menjabat ketua umum Ikatan Cendekiawan Muslim Indonesia DPD Kota Sorong dengan keinginan untuk menyediakan pendidikan bagi generasi muslim. Selanjutnya setelah waqaf, maka dibentuk Yayasan Nurul Yaqin. Dimulai sejak tahun 1992, walaupun secara operasional berjalan secara lancar 1994 dengan penerimaan santri. Salah satu aktivitas yayasan di fase awal dengan membentuk panti asuhan untuk menampung muslim Papua yang berasal dari jauh. Bagi anak-anak didik yang menghuni panti asuhan, mereka dibebaskan dari kewajiban pembayaran. Adapun proses pendidikan tetap sama dengan santri yang lain. Ini didasari sejak awal misi yayasan untuk memberikan penguatan kapasitas kepada generasi muda Islam terutama yang tidak mempunyai akses terhadap pendidikan keagamaan.

Muslim di Papua Barat dengan kemajemukan menemukan tantangan dan sekaligus mendapatkan peluang. Kedua hal ini kemudian menjadi dinamika lembaga pendidikan. Pesantren Nurul Yaqin, Kabupaten Sorong dengan komponen pendukung yang ada berusaha memberikan pelayanan pendidikan kepada umat Islam. Secara unik, lembaga pendidikan ini justru didirikan oleh umat Islam yang sehari-hari 
berprofesi sebagai birokrat. Atas keprihatinan tidak tersedianya lembaga yang memberikan transformasi ilmu pengetahuan kepada generasi muda Islam. Padahal dalam kemajemukan dan kehidupan dengan penganut agama lain, umat Islam rentan dari degradasi keimanan. Dimana identitas keislaman tidak tumbuh dalam pelbagai interaksi kehidupan antar sesama penganut agama. Setelah proses kelembagaan selesai, maka untuk operasional sehari-hari dijalankan oleh guru-guru dan pimpinan yang sebagian besar pendatang. Namun dari sebagian besar itu terdapat juga pimpinan justru dari Papua muslim.

Posisi strategis pesantren dan madrasah di Tanah Papua, sebagai pendukung keberadaan Muslim Papua. Tidak saja karena Papua juga menerima Islam melainkan kedatangan Islam dibandingkan dengan agama lain justru lebih awal. Beberapa suku yang sejak 1700-an sudah menerima Islam secara turun temurun antara lain Kokoda, Inawatan, Arguni, dan Arandai. Karena ketiadaan lembaga pendidikan Islam, maka suku-suku ini dalam beberapa kasus akhirnya menempuh pendidikan di lembaga pendidikan agama lain. Sekaligus secara tidak sadar terjebak dalam tradisi agama yang menaungi lembaga pendidikan tersebut. Untuk itu, kehadiran pesantren dan madrasah menjadi sarana dalam penyadaran identitas keislaman. Dengan pergaulan antara sesama warga, kadang umat Islam tidak lagi menyadari bagaimana seharusnya berperilaku sesuai dengan tuntunan agama. Heterogenitas dan kemajemukan kadang memberikan kebiasaan yang mungkin saja bertentangan dengan pedoman keislaman. Maka, melalui pendidikan ini dapat dibangkitkan kesadaran untuk senantiasa menjadi agama sebagai pegangan. Termasuk pergaulan dengan umat agama lain.

Begitu pula kehadiran pendatang dengan budaya Islam yang ada di tanah kelahiran berusaha untuk memberikan pendidikan kepada keluarganya dengan pola pendidikan Islam. Namun demikian, tidak mudah menemukan lembaga pendidikan Islam dalam skala muslim minoritas. Dengan demikian, kehadiran Pesantren Nurul Yaqin menjadi alternatif bagi keluarga dengan kebutuhan akan pemahaman Islam lebih baik. Strategi pembelajaran diarahkan untuk penguasaan kemampuan dan keterampilan keagamaan. Bukan saja dalam bentuk hafalan tetapi bagaimana Islam kemudian menjadi praktik sehari-hari. Pada tingkatan awal, penekanan hafalan digunakan sebagai sarana untuk mengamalkan ajaran agama. Pada saat sudah dihafalkan terutama dalam bacaan shalat dan ibadah lainnya, maka pemahaman menjadi kunci kegiatan. 
Guru dan pengasuh menggunakan catatan historis setiap santri dan santriwati. Dengan menggunakan ini, maka kesinambungan pembelajaran dapat dipantau secara terus menerus. Begitu pula dapat dilakukan oleh siapa saja oleh guru yang bertugas. Sehingga ketergantungan terhadap satu instruktur saja, tidak akan terwujud. Sekaligus, ini dalam upaya membangun sikap keberagamaan santri dan santriwati. Catatan-catatan ini dimaksudkan sebagai usaha untuk membangun realitas yang kemudian dapat dievaluasi. Pada saat yang sama sikap positif dan sikap negatif kemudian tidak dapat dibentuk di satu sisi. Kemudian di sisi lain menghancurkan sikap negatif. Tetapi dengan adanya catatan, akan memberikan pemaparan sekaligus membantu menyingkirkan halangan dalam proses pembelajaran yang ada. Catatan juga digunakan dalam rangka memahami kompleksitas perkembangan santri dan santriwati sebagai remaja. Reorientasi pengalaman dan pemikiran, termasuk di dalamnya aspek komunikasi menjadi keperluan. Ketika kebudayaan sudah tertanam sebagai bagian dari keberadaan seorang manusia, maka akan menjadi ekspresi, cara pandang, dan bertindak.

\section{E. Pengembangan Kurikulum Pendidikan Agama Islam}

Sejak awal dasar filosofis yang digunakan bahwa pendidikan Islam tidak mengenal dikotomi keilmuan sehingga ilmu yang dipelajari adalah semuanya dalam nuansa keislaman. Prinsip pengetahuan dan aktivitas dalam menekuni ilmu adalah karena Islam memberikan landasan bagi pengembangan ilmu tersebut. Bukan didasarkan dan mengadopsi ilmu yang berasal dari Eropa atau Amerika Utara. Tauhid menjadi dasar utama sekaligus sebagai sentral dari seluruh prinsip yang dijalankan. Agama setara dengan ilmu pengetahuan, tetapi kemudian agama jugalah yang memandu jalannya ilmu pengetahuan. Prinsip ini juga ditopang oleh tauhid. Sehingga ilmu yang dipelajari di pesantren semata-mata adalah ilmu yang tidak parsial. Sebaliknya terintegrasi dengan semangat keberagamaan.

Kebenaran yang digunakan sebagai landasan keilmuan berlandaskan pada al-Quran dan Hadist. Kemudian prinsip khusus yang digunakan adalah aspek keilmuan tidak memihak kepada pemahaman madzhab tertentu. Tetapi semua madzhab dan aliran yang berkembang diajarkan untuk dijadikan sebagai wawasan keilmuan. Tidak dimasukkan ke dalam kurikulum, ajaran yang dianggap mayoritas ulama sebagai menyimpang 
atau tidak dijadikan sebagai materi pelajaran dalam dunia Islam. Ini semata-mata untuk menyiapkan santri agar dapat menjadi anggota masyarakat yang berdiri di atas semua golongan. Pada saat yang sama tidak memihak kepada golongan tertentu. Dengan kondisi umat Islam yang mudah terpecah-belah, maka diharapkan lulusan pesantren akan memenuhi harapan dan kebutuhan masyarakat. Menjadi pionir dimana ia berada, selanjutnya akan menjadi jawaban atas masalah dalam situasi dan kondisi apapun masyarakatnya.

Sebagai respon atas masyarakat yang majemuk tidak saja dalam konteks eksternal, terlebih lagi dalam kondisi internal umat Islam, maka tujuan pembelajaran yang ditetapkan adalah bagaimana santri dapat merespon perubahan kondisi ketika berada di luar pesantren. Masyarakat sebagai supra sistem, dijadikan sebagai tujuan dan sasaran. Perubahan lingkungan berlangsung setiap detik, oleh karenanya santri sejak awal ditujukan untuk menjadi anggota masyarakat yang berubah secara terus menerus. Untuk menghadapi itu semua, santri dilengkapi dan ditunjang dengan pelbagai keterampilan agar supaya mampu mengarungi setiap konsekuensi perubahan masyarakat dan lingkungan. Maka Islam menjadi solusi beserta seluruh perangkatnya. Dimana ajaran tauhid dan keislaman dijadikan sebagai materi utama. Pemahaman terhadap al-Quran dan Hadis menjadi pondasi awal. Untuk itu, keterampilan yang paling awal dilatihkan adalah membaca al-Quran.

Pembelajaran diarahkan dalam bentuk pengelolaan lingkungan pembelajaran dengan usaha untuk memberikan suasana belajar dengan tujuan siswa dapat mencapai tujuan pembelajaran yang ditetapkan. Dua hal yang selalu ditekankan untuk dicapai dalam memaknai proses pembelajaran yang berlangsung adalah perubahan perilaku dan hasil dari interaksi antar sesama dalam lingkungan pondok. Tidak saja untuk santri dengan guru. Bahkan sampai pada santri dengan sesama santri. Termasuk juga santri denagan lingkungan pendukung lainnya yang berada dalam wilayah pondok pesantren. Ada proses belajar secara total dalam sistem sosial yang dibangun bersama. Ketika belajar, maka siswa menjadikan pribadinya sebagai refleksi terkait dengan materi belajar yang ada. Sementara guru mengajar dengan kepribadian yang ada dan bertindak dalam bingkai tindakan professional. Pada saat yang sama ada kewajiban dan ada hak yang berlangsung. Hubungan antara santri dan guru terbentuk dalam pembelajaran berupa instruksional. 
Selanjutnya tujuan pendidikan yang ditetapkan dijabarkan ke dalam isi pendidikan berupa materi pelajaran. Dengan membagi-bagi materi ke dalam pelajaran secara khusus akan memudahkan merumuskan tujuan pembelajaran setiap mata pelajaran. Pengetahuan, sikap dan keterampilan dipetakan masing-masing dalam setiap pelajaran. Secara simultan dimasukkan ke dalam urutan belajar. Begitu juga disusun pedoman yang akan digunakan guru selama proses berlangsung. Ini dirancang dengan mudah karena menggunakan materi pelajaran yang sudah tersusun sebelumnya dari Pesantren Darussalam Gontor. Sehingga modifikasi sesuai dengan keadaan lingkungan Kabupaten Sorong kemudian dilakukan seperlunya. Organisasi bahan dan alat pembelajaran disesuaikan juga dengan kelengkapan pembelajaran yang ada.

Dalam proses pendidikan di Pesantren Nurul Yaqin diawali dengan sistem pendidikan salafi. Dengan tidak menerapkan pendidikan formal dan kurikulum baku. Seiring dengan tuntutan dunia pendidikan dan kebutuhan akan formalitas pendidikan, maka dibentuklah lembaga pendidikan dengan berafiliasi ke Sekolah Menengah Pertama Islam Terpadu dan Madrasah Aliyah. Kurikulum yang tersedia sesuai dengan ketetapan pemerintah tetap dijalankan sesuai dengan standar kompetensi yang sudah digariskan. Pemilihan kurikulum didasarkan pada pertimbangan bahwa sesungguhnya kurikulum merupakan bagian dari adminsitrasi pendidikan. Sehingga dengan menggunakan kurikulum pendidikan yang sudah ada akan lebih mudah diiplementasikan. Dimana sudah melalui uji publik dan penyusunan yang dilakukan oleh sarjana pakar. Dengan demikian, kurikulum ini sudah dalam bentuk yang ideal dan dengan mengadopsi kurikulum tersebut akan mendukung penguatan kelembagaan yang sementara dijalankan.

Dalam proses pendidikan pesantren ditambahkan dengan pendalaman materi berupa kajian kitab klasik. Sementara itu, untuk memenuhi kebutuhan akan alat kajian, maka intensifikasi bahasa Arab diajarkan sejak awal. Penggunaan waktu pembelajaran bahasa Arab dilakukan dalam jam pelajaran dengan jumlah mencapai lima jam sehari. Ini diluar dari kurikulum madrasah yang dilangsungkan pada pagi hari. Pengayaan bahasa Arab juga dilangsungkan di dalam asrama santri. Pembina bahasa secara khusus memberikan tutorial baik sebelum pendidikan formal di madrasah maupun setelah pendidikan formal berlangsung. Termasuk juga dilaksanakan pengajian kitab di 
masjid. Pendidikan yang ada dalam bentuk formal dipandang belum mampu memberikan bekal seutuhnya kepada santri dan santriwati. Sehingga dengan penambahan aktivitas seperti ini setelah usai jam pelajaran formal, akan menyingkirkan kekurangan yang ada. Dengan keseluruhan proses ini, akan membentuk konseptual santri dan santriwati dalam beragama secara sempurna. Pesantren hanya menjadi latihan, tetapi sesungguhnya hasil pendidikan baru dapat dilihat jika sudah meninggalkan wilayah pesantren.

Untuk melengkapi keterampilan santri dalam membaca kitab-kitab klasik, maka proses pendidikan formal ditambahkan dengan literatur yang berasal dari khazanah kitab kuning. Sepenuhnnya praktik yang dijalankan menggunakan sistem pendidikan Gontor dengan modifikasi sesuai dengan kemampuan siswa. Input siswa yang berasal dari regional Papua Barat seperti Bintuni dan Raja Ampat sehingga kemampuan awal siswa sangat heterogen. Ini menjadi tantangan tersendiri dan dapat diatasi melalui matrikulasi pada bulan-bulan awal. Program yang dilaksanakan juga berupa pengayaan materi di sore hari terutama untuk mata pelajaran pondok. Kelas takhashus juga dibentuk dengan bantuan santri senior untuk memberikan pendalaman kemampuan bagi santri yang belum memadai.

Bentuk evaluasi yang digunakan tidak semata-mata hanya berdasarkan keterampilan kognitif. Lebih dari itu, pengamalan ibadah dalam kehidupan sehari-hari menjadi tumpuan yang lebih utama. Dalam satu mata pelajaran, ada beberapa bentuk evaluasi yang disesuaikan dengan karakteristik materi pelajaran itu sendiri. Pelbagai metode evaluasi diterapkan untuk memberikan kemampuan yang memadai bagi santri dengan tidak menjadikan evaluasi sebagai tujuan. Melainkan sebagai sarana untuk meningkatkan kemampuan santri itu sendiri. Fleksibilitas evaluasi semata-mata ditekankan untuk menghasilkan lulusan yang memahami secara sempurna pengetahuan yang didalaminya. Setelah usai menempuh pendidikan kemudian berhenti atau bahkan lupa sama sekali terhadap apa yang sudah dipelajarinya. Kesinambungan pengetahuan dan keterampilan itu diharapkan karena sebagai keterampilan keagamaan, tidak saja ketika di bangku sekolah tetapi lebih dari itu sampai akhir hayat.

Tujuan evaluasi dan kompetensi yang diukur sudah menjadi kelengkapan yang tidak terpisahkan dari penyusunan kurikulum 
sejak awal. Tujuan yang ingin dicapai dari kegiatan evaluasi sudah termaktub secara jelas. Evaluasi yang digunakan mempunyai beberapa karakteristik antara lain (a) perbaikan pada proses pembelajaran, (b) mengadministrasikan pencapaian kemampuan siswa, (c) mengidentifikasi kesulitan apa saja yang dihadapi santri dalam belajar, (d) penempatan santri sesuai dengan kemampuan yang diperolehnya. Ketercapaian kompetensi juga diusahakan pada lintas mata pelajaran, termasuk pada kompetensi antarrumpun pelajaran. Ukuran selanjutnya adalah komptensi lulusan yang dipantau sejak awal begitu santri masuk dari kelas satu sampai ke kelas enam dengan tingkatan madrasah aliyah. Dengan pola pembelajaran yang sistematis dan dikondisikan untuk mencapai target kemampuan yang ditetapkan, maka santri harus merefleksikan kemampuan yang dicapainya dalam bentuk nilai-nilai dasar dalam kehidupan pesantren. Harapannya tidak saja dalam lingkungan pesantren, saat tamat dan tidak lagi berada dalam lingkungan pesantren tetap saja mengamalkan nilai yang sudah diperoleh di madrasah.

Tantangan dalam mewujudkan itu semua adalah bagaimana tetap mempertahankan perhatian santri di satu sisi. Sementara sisi yang lain adalah menumbuhkan motivasi untuk tetap memicu aktivitas-aktivitas pembelajaran. Rancangan kegiatan pendukung senantiasa juga diperhatikan. Untuk mencapai hasil yang optimal, maka perhatian siswa dianggap sebagai modal awal. Pemusatan pikiran dan juga mengelola emosional santri senantiasa menjadi tugas guru untuk memberikan bahan pelajaran yang menarik dan dibutuhkan santri. Ditambahkan pula aktivitas fisik dan psikis berupa shalat tahajjud dan shalat dhuha. Bacaan Quran secara sendiri dan berjamaah juga dilakukan secara terjadwal. Di samping sebagai kewajiban bagi setiap santri juga dijadikan sebagai alat untuk tetap mempertahankan minat santri untuk terus belajar. Dalam kondisi umur mereka yang masih sangat labil, maka santri senantiasa didorong untuk menumbuhkembangkan kebersamaan dan kerjasama dalam proses belajar. Sangat disadari oleh Majelis Guru bahwa dengan bangkitnya motivasi santri, akan menjadikan pembelajaran aktif dan dinamis untuk mencapai tujuan dan hasil belajar yang diinginkan. Dorongan untuk melakukan sesuatu, kemauan dan keinginan yang berlangsung secara simultan merupakan respon positif yang tidak sekedar mengolah informasi. Lebih dari itu, menjadikan informasi sebagai transaksi untuk ditransformasi dalam kehidupan yang lebih luas. 
Dalam proses pembelajaran, maka majelis guru dan pimpinan pondok senantiasa terbuka untuk menerima kontribusi pemikiran dalam rangka pengembangan dan pengayaan kurikulum. Untuk itu, secara berkala mengundang pakar pendidikan dan juga berkomunikasi dengan pimpinan pondok pesantren lainnya yang sudah lebih dahulu berkembang. Ini dimaksudkan bahwa proses inovasi tidak bisa berhenti, sebaliknya senantiasa dilakukan olah-sistem sesuai dengan dinamika sosial masyarakat. Walaupun tahapan-tahapan pengembangan kurikulum dilakukan secara berkala tetapi kesempatan untuk menerima gagasan senantiasa terbuka dari waktu ke waktu. Proses komunikasi dengan pemangku kepentingan dilakukan secara berjenjang, melalui saluran komunikasi yang beragam, dan berlangsung sepanjang waktu. Walaupun tidak mudah, namun adopsi dan benchmarking diusahakan untuk memecahkan masalah yang ada. Penyempurnaan juga dilakukan dalam sarana pendidikan dan terlebih khusus berkenaan dengan media pembelajaran. Untuk itu, untuk menunjang berkembangnya inovasi maka selalu dibuka kemungkinan untuk mendiskusikan pengalaman baru atau temuan penelitian yang mutakhir. Ini dilakukan dalam rangka membangun kekompakan dan kesepahaman agar supaya nilai yang berkembang sejalan dengan keterbukaan untuk selalu menerima gagasan-gagasan baru. Sekalipun itu dari luar pondok.

Kurikulum madrasah didorong untuk dijadikan sebagai sarana membangun harmoni, dan menghindari konflik. Agama senantiasa menjadi sarana dalam kehidupan publik. Agama melalui pendidikan juga kemudian dijadikan sebagai bagian yang inheren dalam kesadaran kolektif. Sehingga ritual agama tidak menjadi terasing dari lingkungan yang dinamik. Sebaliknya agama harus diinternalisasi sekaligus untuk menjamin keutuhan spiritualitas bahkan itu di luar tempat ibadah. Kebenaran agama tidak saja berada di ruang ibadah tetapi harus menjangkau terminologi kebenaran di luar pagar sarana ibadah sekalipun. Dengan kesinambungan perubahan yang senantiasa berlangsung mengiringi waktu, maka proses ini juga direspon dengan kesediaan untuk merespon realitas yang aktual.

Ada realitas yang berlangsung secara cepat, sehingga akan mempengaruhi jalannya masa depan. Ide masa kini senantiasa digunakan untuk kepentingan masa depan. Untuk itu, ketertutupan menjadi suatu hal yang tidak dijadikan sebagai pijakan dalam pendidikan di Pesantren Nurul Yaqin. Hubungan antara pesantren dengan masyarakat 
terwujud dalam bentuk mutual. Pesantren menjadi sumber pendidikan. Sebaliknya masyarakat dijadikan oleh pesantren sebagai mitra dalam mendorong pemahaman dan sekaligus memfasilitasi santri dalam bentuk pengalaman-pengalaman yang bertujuan untuk menjadi proses pembelajaran. Rangkaian tindakan dan partisipasi itu akan memungkinkan seorang santri untuk merekontruksi sebagai pengalaman belajar yang didapat dari masyarakat. Tuntutan ini mengemuka dalam upaya untuk memberikan kesempatan otentik dan bermakna. Sekaligus pada tahapan tertentu menjadikan santri akan bertanggungjawab dalam pilihan atas tindakan-tindakan yang dilakukan. Kesalahan, kegagalan, dan juga kealpaan justru adalah hasil yang dapat dijadikan sebagai media belajar. Bukan dimaknai dalam arti yang negatif, tetapi justru kesempatan untuk belajar secara langsung dari apa yang didapati.

Pemahaman kontekstual di sini digunakan untuk memberikan gambaran yang utuh. Selama ini, kadang proses pendidikan hanya menyandarkanpada kecenderungan pemahaman yang parsial. Untuk itu, fenomena sosial dimana pesantren berada dalam masyarakat muslim minoritas menjadi kesempatan dan peluang untuk memahami rekaman historisitas. Hikmah dari syariat menjadi sebuah perbandingan dengan tidak memahami kecenderungan secara harfiah. Maka, pesantren membangun kurikulum dalam rangka menjawab persoalan-persoalan yang mengitari umat Islam. Orientasi yang dilakukan dalam konteks kekinian dan penerimaan terhadap kondisi realitas masyarakat yang majemuk dan plural. Berdampingan dengan pemeluk umat beragama selain Islam dapat menjadi sebuah tantangan tersendiri dalam merumuskan kurikulum yang dijadikan sebagai materi belajar dalam keseharian.

\section{F. Konstruksi Teoritis}

Penelitian ini kembali menunjukkan keberadaan pesantren sebagai pelopor dalam perubahan sosial. Sebagaimana digambarkan Ziemek (1986) pesantren sejak awal menunjukkan keterlibatan dalam masalah yang ada dalam masyarakat. Sehingga tidak mengherankan kalau kemudian keterlibatan itu selalu saja menjadikan pesantren sebagai pilar dalam aktivitas tersebut. Dengan lingkup utama aktivitas pesantren berada dalam pendidikan keagamaan, maka sesungguhnya interaksi sosial senantiasa melingkupi keberadaan pesantren. Dengan 
mengambil posisi pada struktur pendidikan, ditambah lagi dengan karisma kepemimpinan kiyai menjadikan posisi strategis pesantren sebagai lembaga masyarakat. Perkembangan kelembagaan pesantren secara otonom, tetapi tidak menutup diri dari keterbukaan. Ziemek (1986: 159) memberikan catatan bagaimana pesantren melakukan modernisasi dengan prakarsa yang muncul dari dalam pesantren itu sendiri. Kemudian dengan modernisasi ini memacu diri untuk memberikan kontribusi terbaik bagi lingkungganya.

Justru dengan dinamika kebangsaan yang bersinergi menjadikan pesantren dalam pandangan Mastuhu (1994) sebagai khazanah kebudayaan bangsa. Ada dua hal yang diuraikan Mastuhu merupakan modal sosial utama pesantren yaitu identitas keislaman dan kepedulian terhadap masyarakat. Bahkan jauh hari ketika Indonesia sebagai bangsa belum terbentuk, maka pesantren lebih dulu hadir. Memasuki era perjuangan mendirikan bangsa dimulai, pesantren senantiasa turut serta dalam pergerakan itu. Saat kemerdekaan sudah tercapai, dengan sukarela dan partisipasi penuh pesantren kemudian meleburkan diri dan menjadi sub sistem pendidikan nasional. Maka saat ini, pesantren semakin mengukuhkan diri dengan menjadi multi-dimensi lembaga. Tidak sebatas pada pendidikan, tetapi jauh melangkah melampaui lingkungan pendidikan. Dengan selalu menjadi aktor bagi setiap perubahan dalam lingkungan masing-masing. Ini terjadi, karena pesantren tetap berada di masyarakat. Justru kelahiran yang dibidani masyarakat kemudian dengan mempertahankan dengan senantiasa memenuhi kebutuhan lokalitas.

Kedua penelitian tersebut, merupakan dua penelitian yang menjadi awal bagi penelitian pesantren. Walaupun demikian, kedua penelitian terdahulu tetap menjadi rujukan dan relevan hingga saat ini. Penelitianpenelitian mutakhir dalam satu dekade terakhir tidak saja mengkaji pesantren dalam dimensi pendidikan, tetapi menjangkau dimensi yang tidak secara khusus berkaitan dengan pendidikan. Pada bagian inilah daya dorong pesantren menunjukkan posisi yang khas. Raihani (2012) menunjukkan bagaimana pesantren senantiasa bergelut dengan isu-isu multikulturalisme. Bahkan dengan perjumpaan subyek pendidikan yang berasal dari pelbagai latar belakang dan juga perbedaan ras kemudian mendorong adanya kesefahaman serta pengertian diantara multi etnik. Adapun dua peneliti Buresh (2002) dan Permani (2009) memberikan penjelasan bagaimana pesantren memiliki kekuatan ekonomi. Kedua 
peneliti tersebut dalam penelitian yang berbeda secara bersama-sama sampai pada kesimpulan yang sama bahwa kekuatan ekonomi pesantren menjadi pilar penggerak kemajuan suatu kawasan. Dengan bergulirnya modal dari daerah yang satu ke daerah yang lain, ditambah dengan kebutuhan pesantren serta pergerakan keuangan secara mikro di saat adanya perhelatan tertentu, ini menjadi sebuah fenomena ekonomi yang riil.

Dua peneliti berikutnya, Vignato (2012) dan Saniotis (2012) menguraikan posisi pesantren dalam kepedulian dalam hal lingkungan dan penanggulangan bencana. Pesantren semata-mata bukan saja mengurusi lingkungan belajar. Dengan dua penelitian ini kemudian menjangkau apa yang menjadi urusan kemanusiaan. Di saat damai, pesantren kemudian menumbuhkan semangat dalam hal ekologi dan lingkungan. Begitu juga saat terjadinya bencana, mereka kemudian terjun ke lapangan untuk memberikan bantuan penanggulangan bencana. Termasuk menangani korban-korban bencana dengan memberikan terapi bagi anak-anak untuk menghilangkan trauma yang berkepanjangan akibat bencana tersebut. Dengan melakukan aksi seperti ini, pesantren secara khusus membangun kepercayaan publik sekaligus sebagai sarana dialog dengan masyarakat. Dalam beberapa hal, kadang kegelisahan pendidikan pesantren hanya mampu dikomunikasikan dalam bentuk mimbar semata. Tetapi dengan keterlibatan secara langsung dalam isu-isu yang aktual seperti ini menjadi pelengkap dari bentuk formal sebelumnya. Tetap saja, dalam kapasitas utama bidang pendidikan menjadi pendukung bagi kelangsungan peran pesantren.

Penelitian ini menunjukkan bahwa pengelolaan pendidikan di pesantren senantiasa menjadi perhatian utama. Dalam hal pengembangan kurikulum, pesantren tidak menjalani secara informal. Melainkan usaha-usaha dalam membangun sebuah kurikulum yang merefleksikan kehendak masyarakat dilakukan secara berkesinambungan. Dengan kondisi masyarakat yang majemuk, Pesantren Nurul Yaqin mengadaptasi semangat itu untuk kemudian diakselerasikan dalam pendidikan formal yang dikelola. Sebagaimana pesantren lain yang berada dalam kawasan muslim minoritas (Wekke, 2012) ada upaya untuk melakukan inovasi dalam bentuk kewirausahaan. Begitu juga tujuan pemberdayaan masyarakat. Pesantren di Kabupaten Sorong menjadikan ini sebagai salah satu misi yang diemban (Wekke, 2011). Dengan kondisi lingkungan di 
muslim minoritas, maka tantangan untuk mendukung kapasitas ekonomi kepada umat Islam merupakan kewajiban dan misi pendidikan. Tanpa memainkan peran seperti ini, transformasi pendidikan dengan tidak menjadikan pemberdayaan masyarakat, akan meninggalkan kewujudan muslim sebagai bagian dari kelangsungan pesantren itu sendiri.

Pendidikan Islam yang ada dalam wilayah Papua Barat senantiasa memberikan daya dukung bagi masyarakat, sebagaimana karakter utama pesantren yang sudah berlangsung sejak awal pendirian pesantren. Praktik yang dijalankan pesantren dalam gambaran seperti ini dimaknai Lukens-Bull (2001) sebagai aksi jihad dalan damai (peacefull jihad). Pesantren menjadi tempat untuk menyemai anak-anak muda yang ahli dalam bidang keagamaan. Dalam skala yang lebih luas kemudian mereka menjadi inspirator dalam lingkungannya masing-masing. Bahkan diantara alumni itu kemudian menjadi pemimpin dalam tingkatan nasional yang senantiasa menjadi aktor bagi usaha-usaha perdamaian. Sementara dalam hal kekerasan yang kemudian mengaitkan dengan pesantren semata-mata merupakan kasus yang tidak berdasar sama sekali. Tidak ada keputusan hukum apapun yang kemudian menunjukkan pesantren menjadi lingkungan yang diwarnai dengan kekerasan.

Akhirnya, penelitian ini menyimpulkan bahwa usaha untuk membangun pendidikan pesantren tidak untuk masa yang sekarang saja. Santri senantiasa dibekali pengalaman belajar untuk hadir di masa yang akan datang. Keterlibatan pesantren dalam membentuk kurikulum yang mengadaptasikan kondisi lingkungan mencerminkan keinginan pesantren untuk melibatkan santri dalam kontekstual terkini. Penyiapan ini dilakukan dalam rangkaian mengemban amanat masa depan. Santri yang ada tidak akan hidup dalam masa lalu. Justru mereka akan hidup sekarang dan yang akan datang. Jikalau pengembangan kurikulum tidak dilakukan dengan usaha yang maksimal dan sempurna, maka bisa saja menjadikan tangga untuk memberikan kegagalan bagi santri dan santriwati. Penelitian ini kembali membuktikan bahwa pesantren menjadikan interaksi dengan lingkungan sebagai wahana untuk menyelenggarakan pembelajaran yang bermutu. 
Ismail Suardi Wekke - Pengembangan Kurikulum Pendidikan ...

\section{G. Penutup}

Artikel ini mengkaji bagaimana kurikulum yang dikembangkan di Pesantren Nurul Yaqin, Kabupaten Sorong, Papua Barat. Kondisi muslim dalam komposisi demografi yang minoritas menjadi lingkungan keseharian madrasah. Interaksi dan perjumpaan dengan warga yang tidak menganut agama seiman kemudian menjadi daya dorong untuk memberikan pengajaran agama yang berorientasi kepada identitas muslim di satu sisi. Pada sisi yang lain, tetap menjadi bagian dari kewargaan yang multireligius dengan tidak menafikan keberadaan warga lain sebagai bagian dari kehidupan itu sendiri. Kemampuan ini senantiasa menjadi keperluan bagaimana seorang muslim mampu untuk hidup di tengah masyarakat dengan perbedaan keyakinan.

Kurikulum pendidikan agama Islam yang dikembangkan di Pesantren Nurul Yaqin juga memperhatikan keperluan santri untuk menghadapi masa depan. Tidak saja dalam skala lokal tetapi juga dipersiapkan persaingan regional dan juga tuntutan global. Aspek ini menjadi perhatian segenap komponen di Pesantren Nurul Yaqin. Mulai dari yayasan sampai kepada pegawai. Sejak awal ketika pesantren didirikan, dimaksudkan untuk menjadi lembaga yang memberikan penguatan kapasitas bagi individu muslim. Pendidikan disadari sejak awal tidak hanya sekedar pemahaman semata tetapi juga secara bersamaan diperlukan tindakan. Sebagaimana tidak sekedar berada dalam tataran konsep tetapi juga diperlukan praktik. Begitu pula bentukbentuk abstrak hanya dapat diverifikasi dengan bentuk kongkret. Pada wilayah inilah pendidikan agama Islam difokuskan.

\section{Daftar Pustaka}

Andaya, Barbara Watson. 2013. New Voices from Southeast Asian Women: A Review Essay. Journal of Southeast Asian Studies. Vol. 44, Nomor 01, Februari: 145169.

Bat, M. dan Fasoli, L. 2013. Action Research as a Both-ways Curriculum Development Approach: Supporting Self-determination in the Remote Indigenous Child Care Workforce in the Northern Territory of Australia. Action Research. Vol. 11, Nomor 1, 52-72.

Baxter, Jane dan Chua, Wai Fong. 2008. The field researcher as authorwriter. Qualitative Research in Accounting \& Management. Vol. 
5, Nomor 2:101-121.

Buresh, Scott Allen. 2002. Pesantren-based Development: Islam, Education and Economic Development in Indonesia [disertasi]. Amerika Serikat: University of Virginia.

Castineira, Anthony R. 2009. Transforming Tradition: A Study Of Leadership And Critical Thinking In Army Curriculum Development [disertasi]. Amerika Serikat: Capella University.

Creswel, John W. 2009. Qualitative, Quantitative, and Mixed Methods Approaches. Edisi ketiga, alih bahasa Achmad Fawaid. Yogyakarta: Pustaka Pelajar.

Dicks, A. P. dan Batey, R. A. 2013. The Organic Curriculum: Development of an Undergraduate Catalytic Chemistry Course. Journal of Chemical Education. Vol. 90, Nomor 4, April :519-520.

Ford, Nigel. 2004. Towards a Model of Learning for Educational Informatics. Journal of Documentation. Vol. 60 Nomor 2:183225.

Gerrard, J; Albright, J; dan Clarke, D. J. dkk, Researching the Creation of a National Curriculum from Systems to Classrooms. Australian Journal of Education. Vol. 57, Nomor 1, April:60-73.

Holden, Rick dan Griggs, Vivienne. 2010. Innovative Practice in the Teaching and Learning of Human Resource Development. Journal of European Industrial Training. Vol. 34 Nomor 8/9:705-709.

Howell, Julia Day. 2010. Indonesia's Salafist Sufis. Modern Asian Studies. Vol. 44, Nomor 05, September: 10291051.

Jannah, Siti Raudhatul. 2012. Kegalauan Identitas: Dilema Hubungan Muslimin dan Hindu di Bali. Jurnal Studi Keislaman Ulumuna. Vol. 16, Nomor 2, Desember:443-464.

Kushnarenko, Valentyna. 2010. International Collaboration in Higher Education: The Canadian-Ukrainian Curriculum Development Partnership [disertasi]. Ontario, Kanada: Ontario Institute for Studies in Education University of Toronto.

Lewis, K. 1936. Principles of Topological Personality. New York: McGrawHill.

Lubis, Maimun Aqsha; Wekke, Ismail S; dan Syafar, Suhartini. 2009. Pelaksanaan Teknologi Komunikasi dan Maklumat dalam Pendidikan: 
Ismail Suardi Wekke - Pengembangan Kurikulum Pendidikan ...

Implementasi di Sekolah Bestari. Dalam Saemah Rahman, Mohd Izham Mohd Hamzah, dan Auzar, Reformasi Pendidikan Serantau [hlm 275-282]. Bangi: Pusat Percetakan dan Penerbitan Universiti Kebangsaan Malaysia.

Lukens-Bull, R. A. 2001. Two Sides of the Same Coin: Modernity and Tradition in Islamic Education in Indonesia. Anthropology and Education Quarterly. Vol. 32, Nomor 3:350- 372.

Mastuhu. 1994. Dinamika Sistem Pendidikan Pesantren: Suatu Kajian Tentang Unsur dan Nilai Sistem Pendidikan Pesantren. Jakarta: INIS.

Mazzarol, Tim; Soutar, Geoffrey Norman; dan Seng, Michael Sim Yaw. 2003. The Third Wave: Future Trends in International Education. International Journal of Educational Management. Vol. 17, Nomor 3:90-99.

Medoff, Marshall H. 2008. The Effect of Abortion Costs on Adoption in the USA. International Journal of Social Economics. Vol. 35, Nomor 3:188-201.

Moore, David Thornton. 2004. An Educational Perspective on the Workplace as a Learning Environment. The Journal of Workplace Learning. Vol. 16 Nomor 6:325-340.

Muhaimin. 2005. Pengembangan Kurikulum Pendidikan Agama Islam, di Sekolah, Madrasah dan Perguruan Tinggi. Jakarta: Raja Grafindo Persada.

Nir, Adam E; dan Eyal, Ori. 2003. School-based Management and the Role Conflict of the School Superintendent. Journal of Educational Administration. Vol. 41, Nomor 5: 547-564.

Osteneck, Ursula. 2011. The Experiences of Women Involved in an International Curriculum Development Project [disertasi]. Saskatoon, Kanada: University of Saskatchewan.

Permani, Risti. 2009. The Economics of Islamic Education: Evidence from Indonesia [tesis]. Australia: University of Adelaide.

Putra, Nusa. 2012. Metode Penelitian Kualitatif Pendidikan. Jakarta: RajaGrafindo Persada.

Raihani, 2012. Report on Multicultural Education in Pesantren. Compare: A Journal of Comparative and International Education. Vol. 42, Nomor 4:585-605. 
Salamah, Mansour A. M. Bin. 2001. An Investigation of the Relationship between Saudi Teachers' Curriculum Perspectives and their Preference of Curriculum Development Models [disertasi], Morgantown, Amerika Serikat: West Virginia University.

Saniotis, A. 2012. Muslim and Ecology: Fostering Islamic Environmental Ethics. Contemporary Islam. Vol. 6, Nomor 2: 155-171.

Siler, Jill Marie. 2009. Using Data to Guide Curriculum Development: How Curriculum Developers Use Formative and Summative Assessment Data to Inform the Written Curriculum [disertasi]. Texas, Amerika Serikat: The University of Texas at Austin.

Smith, Barbara Leigh dan MacGregor, Jean. 2009. Learning Communities and the Quest for Quality. Quality Assurance in Education. Vol. 17, Nomor 2:118-139.

SmithHefner, Nancy J. 2008. Review of Robert Folger 'Images in Mind: Lovesickness, Spanish Sentimental Fiction and "Don Quijote." The Journal of Asian Studies. Vol. 67, Nomor 02, Mei:747749.

Tibble, Cindy. 2009. Cultivating an Ecological Consciousness: Appreciative Inquiry for Curriculum Development in Environmental Education [disertasi]. Amerika Serikat: Prescott College.

Vignato, S. 2012. Devices of Oblivion: How Islamic Schools Rescue 'orphaned' Children From Traumatic Experiences in Aceh (Indonesia). South East Asia Research. Vol. 20, Nomor 2:239261.

Wekke, Ismail Suardi. 2011. Pendidikan Islam dan Pemberdayaan Masyarakat (Tinjauan Pendidikan Vokasional Pesantren Roudhatul Khuffadz, Sorong). Jurnal Kajian Interdisipliner Hermenia. Vol. 10, Nomor 1, Desember:23-53.

Wekke, Ismail Suardi. 2012. Pesantren dan Pengembangan Kurikulum Kewirausahaan: Kajian Pesantren Roudahtul Khuffadz Sorong Papua Barat. Jurnal Penelitian Sosial Keagamaan Inferensi. Vol. 6, Nomor 2, Desember:205-226.

Wertheimer, M. 1945. Productive Thinking. New York: Harper \& Row. Ziemek, Manfred. 1986. Pesantren Dalam Perubahan Sosial. Jakarta: P3M. 
